\title{
New Methods, New Opportunities. Recent Advances in Archaeological Science and their Application in Arms and Armour Studies
}

Nowe metody, nowe możliwości. Ostatnie osiągnięcia badań technologicznych w archeologii i ich zastosowanie w studiach bronioznawczych

\begin{abstract}
The jubilee of Professor Andrzej Nadolski and Professor Marian Głosek is an excellent opportunity for discussing some most recent methods of technological analyses in archaeology and their applications in arms and armour studies.

New opportunities are offered by Computed Tomography (Ст) and by Neutron Imaging (NI). The latter is insensitive to material density; therefore details that are not detectable by $\mathrm{x}$-ray or CT can be seen in NI images.
\end{abstract}

A considerable progress has also been made in the field of radiocarbon dating. Yet another field are analyses of the chemical composition of smelting slag and slag inclusions in ferrous artefacts. Such analyses can be used for identification of smelting processes, as well as for provenance studies. These take a number of variables into consideration (major and trace elements, as well as isotopic ratios). What seems to be especially promising in provenance studies are isotopes of osmium (os).

Keywords: Prof. Andrzej Nadolski, Prof. Marian Głosek, archaeological science, archaeometry, archaeometallurgy of iron, non-invasive examinations, arms and armour studies

It is beyond doubt that Professor Andrzej Nadolski and Professor Marian Głosek are among the most prominent and authoritative researchers in the field of arms and armour studies of our days. In many of their influential works, both scholars often underlined the significance of technological examinations of old weaponry as one of the best ways to answer questions concerning issues of chronology, provenance, manufacturing technology or authenticity of artefacts (e.g., Nadolski 1994a: 49; 1994b: I21; Głosek, Nadolski 1970: 24; Głosek 1984: 129, 134; 1990: II5; 1998: 28-29; 2001: 103). In one of his works concerning the Polish coronation sword (known as the Szczerbiec or the Jagged Sword), Professor Nadolski openly stated that technological and physicochemical examinations were indispensable from the point of view of present-day arms and armour studies (Nadolski 1968: IIO). In recent years there has been a considerable progress in many fields 
of archaeological science. It seem therefore that the jubilee of Professor Nadolski and Professor Glosek is a perfect opportunity to discuss some recent developments and their possible applications in arms and armour research.

\section{Non-invasive examinations of artefacts}

At present, the only possible way to obtain comprehensive information about metal artefacts (chemical composition, including that of slag inclusions, microstructures, technology of manufacture) are invasive analyses, which either involve sampling or surface polishing. The latter are obviously not ideal, as they hardly render it possible to get insight into the internal structure of the studied artefact. In recent years many museums and other institutions that store archaeological finds have become more and more reluctant to grant permissions for sampling, which is naturally a serious impediment in technological studies.

Conventional $\mathrm{X}$-ray examinations are already a well-established research method in archaeology. New opportunities have been offered by the application of Computed Tomography (Ст). In contrast to traditional X-ray studies, in which the analysed artefact is examined by $\mathrm{X}$-rays from a fixed tube, СT makes use of a motorised source of $\mathrm{X}$-rays. It rotates around the examined find, while the find itself can also be moved through the opening around which the $\mathrm{X}$-ray source rotates. Thus, it is possible to obtain a series of cross-sectional images of the studied artefact. These can be combined together to form a $3 \mathrm{D}$ image of the examined find.

A good example of the CT application in arms and armour research is a study of early medieval sword blades $\left(6^{\text {th }}-8^{\text {th }} c\right.$.) from Westphalia and some other regions. As these artefacts were display items, the use of non-destructive methods was an indispensable prerequisite. Examinations were carried out using an industrial CT device equipped with a $225 \mathrm{kV}$ X-ray source and with a 1024 x 1024 pixel detector. In result, it was demonstrated that many examined blades were manufactured using pattern-welding technology. It was stressed that a special advantage of the Ст method consisted in the fact that layered images allowed for a reconstruction of original welding patterns (Lehmann 2013: 39-42). This method was also successfully applied in the examinations of an $8^{\text {th }}$ c. sax blade from Grave 160 in Haltern-Flaesheim in Westphalia. This artefact was forged from a spatha blade and it was found out that it was forge-welded from eight pieces - two edges and six pattern-welded and twisted rods that formed the core of the blade (Lehmann, Müsch 2010: 118-I20).

A viable and in some cases more effective alternative to CT examinations is offered by the Neutron Imaging (NI) method. In this case, the studied artefact is penetrated not by $\mathrm{X}$-rays but by neutrons. Its image is based on different neutron attenuation properties of a given material. As opposed to X-ray attenuation, which 
is chiefly related to the density of materials, neutron attenuation is not a function of material density. Thanks to this, numerous traits of the analysed find which may not be observable with the use of methods based on X-ray imaging can easily be seen on NI images.

The NI method was successfully applied in a study of three Viking Age swords from the National Museum of Denmark. In result, it was not only demonstrated that their blades were made using pattern-welding technology and their cores were composed of twisted rods with layers of soft iron and steel. What is more, it also proved possible to determine individual phases in the metal (ferrite, cementite and slag inclusions), due to their different attenuation properties. Moreover, the presence and position of welding lines, cracks and corrosion products could also be identified (Fedrigo et al. 2016: 1249-1262).

\section{New developments of radiocarbon dating}

Radiocarbon dating which originated in the 1940s has for long been a well-established method of chronology assessment in archaeology. However, problems could be posed by the necessary size of samples for analyses, which usually was in the order of some dozen or so grams. While this is not a serious impediment in the case of, e.g., large fragments of construction timber, such a size could be a major obstacle for ferrous alloy artefacts. On the other hand, in the end of the $20^{\text {th }} \mathrm{c}$. this method was refined and it became possible to obtain reliable dating with samples of merely a few $\mathrm{g}$. Their exact weight depends on the content of $\mathrm{C}$ - while at least $5 \mathrm{~g}$ may be needed in the case of low-carbon wrought iron, for high-carbon cast iron with $2 \% \mathrm{C}$ only roo $\mathrm{mg}$ is necessary (see, e.g., Cresswell 1992: 898-90I; see also Gassmann, Schäfer 2018 for a discussion on contamination-related risks). Concerning weaponry studies, this method was successfully applied to two medium-carbon steel Luristan daggers and calibrated dates of 3087-2942 BP and 3214-2993 BP were obtained (Cresswell 1992: 903, Tab.3, 904). This approach can be further refined and combined with detailed metallurgical examinations, as done, e.g., in the case of construction iron (crampons) from the Baphuon Temple in Angkor in Cambodia, thus shedding new light on the building history of this monument (Leroy et al. 2015: I-I2).

It can be hoped that the refined radiocarbon dating method will also be of use for future studies on old arms and armour. The radiocarbon chronology's accuracy is not much greater than more traditional ways of dating (e.g., those based on typology and morphology of artefacts, their inscriptions, ornaments and the like). However, this method can render great service in examinations of finds whose chronology is debatable and which cannot be reliably dated otherwise, due to their vestigial state of preservation, absence of archaeological context and so on. 
This is the case, for instance, with a possibly Roman Period sword from Grzybowo (Grzybowen) in Prussia. Its morphology may find some counterparts in existing typologies of Roman Period swords. On the other hand, as the weapon was made from virtually slag-free high-carbon steel (about $0.7 \% \mathrm{C}$ ), it cannot be said for certain whether it is very clean bloomery steel, hypoeutectoid crucible steel or Industrial Age metal (on this sword see Żabiński et al. 2016: 97-I22).

\section{Recent advances in slag examinations and their implications}

There is hardly any doubt that slag, be it slag finds as such or slag inclusions in ferrous artefacts, is an extremely important source of data in archaeometallurgical research. It seems that there are two most important fields where this data can be used: provenance studies and identification of smelting processes (bloomery, blast furnace and finery, puddling process, or later mass steelmaking processes of the Industrial Age, such as the Bessemer process and others). It must be remembered, however, that there is one indispensable prerequisite in such studies. Namely, it is necessary to properly identify slag inclusions (SIs) whose chemistry is chiefly related to the smelting process itself, as opposed to those whose chemical composition is influenced by other factors that participate in the ironmaking process, such as technical ceramics (smelting furnace walls), fuel ash, smelting or smithing additives (e.g., flux), and so on. It is well-known that the chemistry of slag inclusions in ferrous artefacts is extremely heterogeneous, which is partially due to the fact that these inclusions are formed in different stages of the smelting process. On the other hand, V.F. Buchwald and H. Wivel noted that ratios of certain oxides in these inclusions generally remained constant. The ratios of these compounds (sometimes termed NRCs or Non-Reduced Compounds, as they are not reduced during the process) include $\mathrm{MnO} / \mathrm{SiO}_{2}, \mathrm{~K}_{2} \mathrm{O} / \mathrm{Al}_{2} \mathrm{O}_{3}, \mathrm{CaO} / \mathrm{Al}_{2} \mathrm{O}_{3}, \mathrm{SiO}_{2} / \mathrm{Al}_{2} \mathrm{O}_{3}$, or $\mathrm{K}_{2} \mathrm{O} / \mathrm{MgO}$ (Buchwald, Wivel 1998: 74-78, Fig. 5). These scholars also believed that on the basis of differences in values of these ratios it was possible to differentiate the provenance of iron artefacts from Western Denmark (Jutland), the Danish Isles (Fyn and Sjaelland), Sweden and Norway (Buchwald, Wivel 1998: 77, 79-83, Figs. 6-7, Tab. 2). Yet another important observation was that there were differences in the chemical composition of slag inclusions in bloomery iron and in blast furnace refined iron. The blast furnace process (also known as the indirect process, as iron is produced in two stages - smelting and refining) probably first went into use in Sweden in the $12^{\text {th }}$ c. In this case, pig iron is produced first (with c. $3-4 \%$ C) which contains very few slag inclusions which are virtually $\mathrm{FeO}$-free. Malleable (or wrought) iron is then obtained in the refining stage, which also leads to formation of new slag inclusions. Their chemistry is strongly different from that of bloomery process slag inclusions. For instance, in fining slag inclusions the 
ratios of $\mathrm{SiO}_{2} / \mathrm{Al}_{2} \mathrm{O}_{3}$ are higher, while the ratios of $\mathrm{Al}_{2} \mathrm{O}_{3} / \mathrm{CaO}$ and $\mathrm{K}_{2} \mathrm{O} / \mathrm{MgO}$ are lower than in slag inclusions produced by the bloomery process, provided that ores of similar characteristics are used (Buchwald, Wivel 1998: 86-92, Tabs. 3, 4, Fig. 17). What is more, it is also possible to note differences in the chemistry of slag inclusions from the refining process and from the puddling process. In the latter case, the share of $\mathrm{CaO}, \mathrm{K}_{2} \mathrm{O}, \mathrm{Al}_{2} \mathrm{O}_{3}$ and $\mathrm{MgO}$ is much lower and their ratios (e.g., $\mathrm{SiO}_{2} / \mathrm{Al}_{2} \mathrm{O}_{3}, \mathrm{~K}_{2} \mathrm{O} / \mathrm{MgO}$ ) are strongly different (Buchwald, Wivel 1998: 92-93, Tab. 5, Fig. 19). V.F. Buchwald made use of these approaches in his later works (Buchwald 2005; 2008).

The method of distinguishing between iron obtained in the bloomery (direct) process and the blast furnace and refining (indirect) process was further refined by $\mathrm{Ph}$. Dillmann and M. L'Héritier. These researchers observed that it was possible to identify smelting slag inclusions in iron (as opposed to slag inclusions of different provenance) by means of modelling ratios of selected NRCs on biplots. Ratios of $\mathrm{Al}_{2} \mathrm{O}_{3} / \mathrm{SiO}_{2}, \mathrm{~K}_{2} \mathrm{O} / \mathrm{CaO}$, and $\mathrm{MgO} / \mathrm{Al}_{2} \mathrm{O}_{3}$ are plotted and fitted by a linear model passing through $\mathrm{O}$. If the $\mathrm{R}^{2}$ determination coefficient is higher than 0.7 , a constant ratio can be assumed. Thus, by means of eliminating erratic inclusions it is possible to identify those which are related to the smelting process (Dillmann, L'Héritier 2007: 1813-1817, Figs. 2, 4). Furthermore, these scholars observed that certain compounds behaved differently, depending on the smelting process. On the basis of these differences it can be assumed that, when plotted on a graph, blast furnace refined iron will display high values of $\mathrm{wt}_{\mathrm{t}} \mathrm{P}_{2} \mathrm{O}_{5}{ }^{*}$ and low values of ( $\left.\mathrm{wt}^{2} \mathrm{Al}_{2} \mathrm{O}_{3}{ }^{*}+\mathrm{wt} \% \mathrm{MgO}^{*}+\mathrm{wt} \% \mathrm{~K}_{2} \mathrm{O}^{*}\right) / \mathrm{wt}^{2} \% \mathrm{FeO}^{*}$ ( ${ }^{*}$ asterisks mark the so-called weighted content, in which the surface of the analysed slag inclusions is also taken into account). On the other hand, the reverse will be true for bloomery iron artefacts. This approach was based on a reference set of over 170 iron samples (both experimental smelting and archaeological iron) from well-defined contexts. It was assumed that pre-I $4^{\text {th }} \mathrm{C}$. artefacts would come from the direct process. Concerning iron from the $16^{\text {th }} \mathrm{c}$. and later, its indirect process origin was verified with the use of written sources, while finds dated to the transition period between both processes $\left(14^{\text {th }}-16^{\text {th }} \mathrm{C}\right.$.) were omitted (Dillmann, L'Héritier 2007: I8I2-I8I3, Tabs. I-2, I817-I819, Figs. 8-10). Eventually, the method was tested on a set of samples of construction iron from monumental buildings, such as churches and castles. In most cases these samples were dated to the transition period. On the basis of this study it was possible to trace the spread of the application of the indirect smelting process in the manufacture of construction iron in France (Dillmann, L'Héritier 2007: 1812-1813, Tab. 3, 1819-1822, Figs. II-13).

A study by M.F. Charlton et al. was a true milestone in research on provenance of iron artefacts. On the basis of experimentally smelted iron these researchers proposed a method of discrimination between smelting slag inclusions and those 
whose chemistry is more influenced by other components of the smelting operation (technical ceramics, fuel ash, smithing additives, etc.). This is done by using multivariate statistical methods, such as Principal Component Analysis (PCA) and Agglomerate Hierarchical Clustering (AHC), taking six NRCs into consideration: $\mathrm{SiO}_{2}, \mathrm{Al}_{2} \mathrm{O}_{3}, \mathrm{~K}_{2} \mathrm{O}, \mathrm{MgO}, \mathrm{CaO}$ and $\mathrm{TiO}_{2}$. While plotted on a PCA graph, smelting-derived slag inclusions will group near the origin of the graph. Other SIs that will group next to vectors of individual NRCs or their correlated pairs can be identified as those whose chemistry is related to other factors. For instance, observations plotting next to $\mathrm{Al}_{2} \mathrm{O}_{3}, \mathrm{MgO}, \mathrm{SiO}_{2}$ and $\mathrm{TiO}_{2}$ vectors will be related to clay additives, those grouped close to $\mathrm{CaO}, \mathrm{K}_{2} \mathrm{O}$ and $\mathrm{MgO}$ vectors can be linked to ash contamination, while observations plotting next to $\mathrm{SiO}_{2}$ or $\mathrm{Al}_{2} \mathrm{O}_{3}$ can be related to sand additives. This method obviously works best on low-processed artefacts, such as blooms or bars. This is due to the fact that in strongly processed artefacts (e.g., sword blades), the number of smelting-derived sis may be low and their chemistry may be strongly altered by many stages of manufacture (Charlton et al. 20I2: 228I-2285, Tabs. I-2; this method of identification of smelting-related SIs was modified by Disser et al., as a smaller set of NRCs - excluding $\mathrm{TiO}_{2}$ - was considered, and a somewhat different statistical approach was used, see Disser et al. 2014: 322-325; the problem of transformation of sis chemical composition during subsequent stages of manufacture has recently been dealt with by Disser et al. 2020). In order to assess the provenance of a given artefact, Charlton et al. applied a combination of Linear Discriminant Analysis (LDA) and Kernel Density Estimation ( $\mathrm{KDE}$ ), taking the following oxides into consideration: $\mathrm{MgO}, \mathrm{Al}_{2} \mathrm{O}_{3}$, $\mathrm{SiO}_{2}, \mathrm{~K}_{2} \mathrm{O}, \mathrm{CaO}, \mathrm{TiO}_{2}$ and $\mathrm{MnO}$ (Charlton et al. 2012: 2284-2285). The proposed method was first tested on data from smelting experiments (Charlton et al. 20I2: 2285-2290, Figs. I-I2, Tabs. 3-4). Then, it was applied to actual archaeological data provided by V.F. Buchwald (2005) and it was possible to obtain a sufficient separation between the three aforementioned regional groups of smelting slag (Western Denmark, the Danish Islands, as well as Sweden and Norway). Furthermore, the provenance of a majority of artefacts was also properly assessed (Charlton et al. 20I2: 2288-229I, Fig. 3). There are obviously reservations of this method, such as a not always sufficient degree of discrimination between regional groups, their representativeness, or simply the presence or absence of the "true" region of provenance in the analysed dataset. What is more, better results could be obtained by also taking minor oxides and trace elements into consideration. Furthermore, thorough studies on the economy of a given society and its possible iron sources are indispensable (Charlton et al. 2012: 2290-229I).

New studies on archaeological iron made use of these developments. S. Leroy et al. analysed construction iron from $1 \mathrm{I}^{\text {th }}-13^{\text {th }} \mathrm{Khmer}$ capital of Angkor in Cambodia in order to study local iron economy. This study encompassed a classification 
of iron crampons, their radiocarbon dating and identification of smelting systems (Leroy et al. 2018: 2137-2155). M. Brauns et al. made an attempt at using $\mathrm{Os}$ and $\mathrm{Sr}$ isotope ratios for provenance studies (Brauns et al. 20I3: 84I-848). Ph. Dillmann et al. proposed a very interesting and promising approach to provenance studies which combines os isotopic ratios, major elements ( $\mathrm{Mg}, \mathrm{Al}, \mathrm{Si}, \mathrm{K}, \mathrm{Ca}, \mathrm{Mn})$, as well as trace elements (Y, La, Ce, Pr, Nd, Gd, Sm, Eu, Tb, Yb, Th and U). The dataset was then processed using a multi-stage PCA-AHC approach. This method was applied to Early Iron Age $\left(6^{\text {th }}-5^{\text {th }}\right.$ c. BC) finds from the North Alps and the existence of a complex system of iron circulation was found out (Dillmann et al. 2017: 109-I22). The PCA-AHC approach (albeit in a less complex form), as well as major and trace elements data were used in order to identify the provenance of construction iron in Metz Cathedral in France (Disser et al. 2017: 493-508).

Concerning the distinction between the direct and the indirect smelting process, Disser et al. developed a method based on the principle of logistic regression. The final formula is expressed by an equation: $\operatorname{Logit}(p)=\beta^{o}+\beta^{M g}\left[\% \mathrm{MgO}^{* *}\right]+\beta^{A l}$ $\left[\% \mathrm{Al}_{2} \mathrm{O}_{3}^{* *}\right]+\beta^{S i}\left[\% \mathrm{SiO}_{2}^{* *}\right]+\beta^{P}\left[\% \mathrm{P}_{2} \mathrm{O}_{5}{ }^{* *}\right]+\beta^{K}\left[\% \mathrm{~K}_{2} \mathrm{O}^{* *}\right]+\beta^{C a}\left[\% \mathrm{CaO}^{* *}\right]+\beta^{M n}$ $\left[\% \mathrm{MnO}^{* *}\right.$. Double asterisks $\left.{ }^{(* *}\right)$ mark subcompositional ratios of each relevant oxide weighted contents $\left({ }^{*}-\right.$ see above), which were calculated in order to remove a potential data distortion that may be caused by overrepresentation of Fe due to the matrix effect. Eight $\beta$ coefficients were calculated on the basis of a reference set of 138 samples, for which the smelting process was known. The Logit $(\mathrm{p})$ values are strongly positive for the indirect process and strongly negative for the direct process. This method was successfully applied in the analysis of construction iron (6I samples altogether) from Metz Cathedral and Beauvais Cathedral in France (Disser et al. 20r4: 325-332, Tabs. 5-8).

From the point of view of the present paper, of greatest interest are cases of application of these newly developed methods in arms and armour studies. Concerning the discrimination between the smelting processes, a late $14^{\text {th }}-$ early $15^{\text {th }} \mathrm{c}$. plate armour couter has recently been dealt with by the author of this paper and his colleagues. Metallurgical examinations of this artefact proved very instructive from the archaeometallurgical point of view. As its metal underwent many manufacturing stages, it was quite pure and the total number of slag inclusions on the surface of the examined sample was perhaps merely a hundred or so (Imiotczyk et al. 2020: 6-9, Fig. 2-4). In this assemblage, it was possible to examine 43 SIs and out of these it was merely is that could be used in the identification of the smelting process. This was due to the fact that most of these 43 sis were $\mathrm{FeO}$-dominated wüstite inclusions where many relevant oxides were either absent or below detection limits (Imiołczyk et al. 2020: I2, Tab. 4, I3-I4). While attempting at identification of smelting-related sis, a comment was also made on the effectiveness of the $\mathrm{R}^{2}$-based discrimination principle. It was found out that 
this approach alone was hardly of use for highly processed artefacts, as implied by previous scholarship. Eventually, the identification of smelting-related sis was carried out using a combination of available methods. In result of it, only up to five sis could be classified as smelting-related. The identification of the smelting process demonstrated that the discussed artefact was in all probability made from blast furnace refined iron (Imiołczyk et al. 2020: 15-18, Tabs. 7-IO, Fig. 6). This discovery seems to be especially significant, as it was hitherto believed that blast furnace metal first went into use for the purpose of armour manufacture in the $16^{\text {th }} \mathrm{c}$. This assumption was first of all based on very low prices of so-called munition armours, which were mass-made for common soldiers. The low cost of such armours naturally suggests mass supplies of cheap blast furnace refined iron (see Williams 2003: 886-889, 891; 2012: 201, 212-213). The author of this paper and his colleagues undertook yet another attempt at identification of the smelting process concerning the metal of another weaponry artefact. In this case, it was a late medieval or early modern barrel of a hand-held gun (possibly a hackbut) that was later converted into a light cannon. In this case the metallurgical analyses and the statistical processing of data were much simpler, as the metal was not strongly processed and slag inclusions were abundant (Żabiński et al. 2019: 2013-2017, Figs. 7-10). In this case, all available identification methods demonstrated that the metal of the barrel had been obtained in the direct (bloomery) smelting process (Żabiński et al. 2019: 2019, Fig. 12, 2023-2025).

A splendid example of the application of new methods to weaponry provenance examinations is offered by a study of Bérard et al. In this case, it was attempted at identifying the origin of high and late medieval $\left(\mathrm{I}^{\text {th }}-15^{\text {th }} \mathrm{c}\right.$.) Io plate armours of possibly north Italian, south German and east French manufacture on the basis of analysis of trace elements in slag inclusions. Chemical composition data was obtained via LA-ICP-MS (Laser Ablation Inductively Coupled Plasma Mass Spectrometry) and the set of variables taken into consideration for the purpose of provenance analyses included the following trace elements: $\mathrm{Y}, \mathrm{Nb}, \mathrm{Ba}, \mathrm{La}, \mathrm{Ce}, \mathrm{Nd}$, Sm, Eu, Yb, Hf, Th, and U (Bérard et al. 2020: 2583-2588, Tab. I). For statistical processing of data, both PCA and LDA methods were used. It must be said that the final results were not always fully conclusive, also due to the fact that a reference set of ore and slag data from only two regions, that is, Lorraine and Lombardy (Italian Alps) was used. On the other hand, on the basis of the sI chemistry it was possible to isolate different groups of armour. The sI chemical composition of the first group seemed to match the chemistry of a Lorraine ore (so-called Minette). Concerning putative Italian armour, three provenance groups were proposed but none of these fitted within the chemical composition of Lombard ores. This could either mean that Lombard workshops may have used metal of different origin, or that the discussed armour was merely of Italian style and was 
in fact made in another unknown region. Concerning three German armours, it turned out that their chemical signatures were isolated. Eventually, the authors stated that their proposed approach could lay path for more comprehensive trace element studies of ferrous artefacts, with special reference to armour (Bérard et al. 2020: 2588-2591, Figs. 6-8).

\section{Conclusions}

The recent years have witnessed rapid advances in the field of archaeological science. The new methods and approaches that have been developed can also be of extreme use for the purpose of arms and armour studies, as demonstrated by the aforementioned examples. New non-invasive methods, such as the Neutron Imaging, may allow for more detailed examinations of weaponry, especially in cases where no sampling is allowed. Developments in radiocarbon dating can open new perspectives in studies of arms and armour artefacts whose chronology is uncertain, be it due to the lack of proper archaeological context, poor state of preservation or other reasons. More reliable methods of smelting process identification may help respond to a question of significance of the blast furnace (indirect) smelting technology from the point of view of weaponry manufacture.

Significant advances in provenance studies are likely to be a true breakthrough in defining the origin of weaponry. Until recently, a lion's share of attempts at provenance assessment of arms and armour were carried out with the use of "purely" archaeological criteria, such as typology and morphology, ornaments, marks and inscriptions, or possibly the technology of manufacture. There is no doubt that these traditional criteria must not be abandoned and can be further refined. On the other hand, they now receive powerful support from archaeometric analyses. This, of course, will not be an easy task. As said above, chemistry based provenance studies have their own limitations. One of these is a necessity to create a comprehensive comparative database of ore and slag chemistries from different regions, which naturally applies not only to iron, but to other metals as well. All in all, it can be hoped that these difficulties can be to a great degree overcome and students of arms and armour will benefit from new perspectives offered by archaeological science. 


\section{Bibliography}

Bérard E., Pécheyran Ch., Dillmann Ph., Leroy S., Vega E., Williams A., Verna C., Toureille V. (2020), Ancient Armour Provenance by LA-ICP-MS Analysis of Microscopic Slag Inclusions, "Journal of Analytical Atomic Spectrometry", 35, p. 2582-2593, https://doi.org/10.1039/DoJA00259C

Brauns M., Schwab R., Gassmann G., Wieland G., Pernicka E. (2013), Provenance of Iron Age Iron in Southern Germany: a New Approach, "Journal of Archaeological Science", 40, p. 84I-849, https://doi.org/I0.IOI6/j.jas.20I2.08.044

Buchwald V.F. (2005), Iron and Steel in Ancient Times, The Royal Danish Academy of Sciences and Letters, Copenhagen (Historisk-filosofiske Skrifter, 29).

Buchwald V.F. (2008), Iron, Steel and Cast Iron before Bessemer, The Royal Danish Academy of Sciences and Letters, Copenhagen (Historisk-filosofiske Skrifter, 32).

Buchwald V.F., Wivel H. (1998), Slag Analysis as a Method for the Characterization and Provenancing of Ancient Iron Objects, "Materials Characterization", 40, p. 73-96, https://doi.org/10.1016/S1044-5803(97)00105-8

Charlton M.F., Blakelock E., Martinón-Torres M., Young T.(2012), Investigating the Production Provenance of Iron Artifacts with Multivariate Methods, "Journal of Archaeological Science", 39, p. 2280-2293, https://doi.org/I0.1016/j.jas.2012.02.037

Cresswell R. (1992), Radiocarbon Dating of Iron Artifacts, "Radiocarbon", 34.3, p. 898-905, https://doi.org/10.1017/So033822200064225

Dillmann Ph., L'Héritier M. (2007), Slag Inclusion Analyses for Studying Ferrous Alloys Employed in French Medieval Buildings: Supply of Materials and Diffusion of Smelting Processes, "Journal of Archaeological Science", 34, p. 1810-1823, https://doi.org/10.1016/j.jas.2006.12.022

Dillmann Ph., Schwab R., Bauvais S., Brauns M., Disser A., Leroy S., Gassmann G., Fluzin P. (2017), Circulation of Iron Products in the North-Alpine Area during the End of the First Iron Age ( $6^{\text {th }}-5^{\text {th }}$ C. BC): a Combination of Chemical and Isotopic Approaches, "Journal of Archaeological Science", 87, p. 108-124, https://doi.org/10.1016/j. jas.2017.10.002

Disser A., Bauvais S., Dillmann Ph. (2020), Transformations of the Chemical Signature of Slag Inclusions throughout Experimental Refining and First Shaping of Bloomery Iron: New Methodological Developments, "Journal of Archaeological Science: Reports", 34 , Part B, 102653, https://doi.org/10.1016/j.jasrep.2020.102653

Disser A., Dillman Ph., Leroy S., L'Héritier M., Bauvais S., Fluzin P. (2017), Iron Supply for the Building of Metz Cathedral: New Methodological Development for Provenance Studies, "Archaeometry", 59, p. 493-510, https://doi.org/10.1111/arcm.12265

Disser A., Dillman Ph., Bourgain C., L'Héritier M., Vega E., Bauvais S., Leroy M. (2014), Iron Reinforcements in Beauvais and Metz Cathedrals: from Bloomery or Finery? The Use of Logistic Regression for Differentiating Smelting Processes, "Journal of Archaeological Science”, 42, p. 315-333, https://doi.org/10.1016/j.jas.2013.10.034

Fedrigo A., Strobl M., Williams A.R., Lefmann K., Lindelof P.E., Jørgensen L., Pentz P., Bausenwein D., Schillinger B., Kovyakh A., Grazzi F. (2016), Neutron Imaging Study of 'Pattern-welded' Swords from the Viking Age, "Archaeological and Anthropological Sciences", 10.6, p. 1249-1263, https://doi.org/10.1007/s12520-016-0454-5 
Gassmann G., Schäfer A. (2018), Doubting Radiocarbon Dating from in-slag Charcoal: Five Thousand Years of Iron Production at Wetzlar-Dalheim?, "Archeologické rozhledy", 70.3, p. 309-327.

Głosek M. (1984), Miecze środkowoeuropejskie $z X-X V w$. (Central European Swords of the I $^{\text {th }}-15^{\text {th }}$ Centuries), Polska Akademia Nauk, Instytut Historii Kultury Materialnej, Warszawa.

Głosek M. (1990), Broń biata dtuga (Long cold steel), [in:] A. Nadolski (ed.), Uzbrojenie $w$ Polsce średniowiecznej 1350-I450 (Arms and Armour in Medieval Poland 1350-1450), Polska Akademia Nauk, Instytut Historii Kultury Materialnej, Łódź, p. III-I23.

Głosek M. (1998), Broń biata (Cold steel), [in:] A. Nowakowski (ed.), Uzbrojenie $w$ Polsce średniowiecznej I450-I5oo (Arms and Armour in Medieval Poland I450-1500), Uniwersytet Mikołaja Kopernika, Toruń, p. 23-40.

Głosek M. (200I), Stan i potrzeby badań nad uzbrojeniem wczesnego średniowiecza na terenie Europy Srodkowej (State and needs of research on early medieval armament in Central Europe), "Folia Archaeologica", 23, p. 103-II2.

Głosek M., Nadolski A.(1970), Miecze średniowieczne z ziem polskich (Medieval swords from the Polish lands), Łódzkie Towarzystwo Naukowe, Łódź (Acta Archaeologica Lodziensia, 19).

Imiołczyk E., Żabiński G., Goryczka T., Aniołek K., Balińska A., Miśta-Jakubowska E. (2020), An Armour from a Finery? - a Late Medieval Couter from Ogrodzieniec Castle in the Kraków-Częstochowa Jura, "Archaeological and Anthropological Sciences", I2 (6I), p. I-20, https://doi.org/10.1007/si2520-019-00979-I

Lehmann U.(2013), Studien zu frühmittelalterlichen Schwertschmiedetechniken mittels 3-D-Röntgen-Computertomografie, "Archäometrie und Denkmalpflege", p. 38-43.

Lehmann U., Müsch E. (2010), Spatha oder Sax? CT-Untersuchung eines Schwertes aus Haltern-Flaesheim, "Archäologie in Westfalen-Lippe", 9, p. I18-I2I.

Leroy S., Hendrickson M., Delqué-Kolic E., Vega E., Dillmann Ph. (2015), First Direct Dating for the Construction and Modification of the Baphuon Temple Mountain in Angkor, Cambodia, "PLos ONE" Io (II), p. I-I3, https://doi.org/IO.137I/journal.pone.or4IO52

Leroy S., Hendrickson M., Bauvais S., Vega E., Blanchet T., Disser A., Delque-Kolic E. (2018), The Ties that Bind: Archaeometallurgical Typology of Architectural Crampons as a Method for Reconstructing the Iron Economy of Angkor, Cambodia (Tenth to Thirteenth c.), "Archaeological and Anthropological Sciences", IO, p. 2137-2157, https://doi.org/10.1007/s12520-017-0524-3

Nadolski A. (1968), Szczerbiec (próba analizy bronioznawczej) (Szczerbiec: at attempt at weaponry analysis), [in:] A. Nadolski (ed.), Na granicach archeologii (On the borders of archaeology), Łódzkie Towarzystwo Naukowe; Zakład Narodowy im. Ossolińskich, Łódź-Wrocław (Acta Archaeologica Lodziensia, 17), p. 105-I25.

Nadolski A. (1994a), Rozdziat I. Lądowa technika wojskowa od potowy X do potowy $X I I$ wieku (Chapter I. Land military technology since the mid- $\mathrm{IO}^{\text {th }}$ to the mid- $-2^{\text {th }} \mathrm{c}$.), [in:] A.Nadolski (ed.), Polska technika wojskowa (Polish Military Technology), Polska Akademia Nauk, Komitet Historii Nauki i Techniki, Warszawa (Z Dziejów Nauki i Techniki, I), p. 3I-I07.

Nadolski A. (1994b), Rozdziat 2. Lądowa technika wojskowa od potowy XII wieku do roku 1333 (Chapter 2. Land military technology since the mid-12 ${ }^{\text {th }}$ C. to I333), 
[in:] A. Nadolski (ed.), Polska technika wojskowa (Polish Military Technology), Polska Akademia Nauk, Komitet Historii Nauki i Techniki, Warszawa (Z Dziejów Nauki i Techniki, I), p. I08-185.

Williams A.R. (2003), The Knight and the Blast Furnace. A History of the Metallurgy of Armour in the Middle Ages \& the Early Modern Period, Brill, Leiden (History of Warfare, I2), https://doi.org/10.1163/9789004476080

Williams A.R. (2012), The Sword and the Crucible. A History of the Metallurgy of European Swords up to the I $6^{\text {th }}$ Century, Brill, Leiden-Boston (History of Warfare, 77), https://doi.org/IO.1163/9789004229334

Żabiński G., Biborski M., Miśta-Jakubowska E. (2019), A Late Medieval or Early Modern Light Gun Barrel from the Castle Museum in Malbork - Typology, Technology of Manufacture and Identification of the Smelting Process, "Archaeological and Anthropological Sciences", 19, p. 2007-2026, https://doi.org/10.1007/s12520-018-0653-3

Żabiński G., Rzeszotarska-Nowakiewicz A., Nowakiewicz T., Kontny B., Kucypera P. (2016), A Possible Roman Period Sword from Grzybowo (Grzybowen), Masuria, NE Poland. The Archaeological and Technological Context, "Gladius", 36, p. 97-139, https://doi.org/10.3989/gladius.2016.0006

\section{Streszczenie}

Profesor Andrzej Nadolski i Profesor Marian Głosek to niewątpliwie jedni z najwybitniejszych bronioznawców naszych czasów. Wielokrotnie podkreślali oni znaczenie badań technologicznych dawnego uzbrojenia. Jubileusz obu Uczonych jest zatem doskonałą okazją do omówienia niektórych najnowszych metod badań technologicznych $\mathrm{w}$ archeologii i ich możliwych zastosowań w studiach bronioznawczych.

Archeologia od dawna wykorzystuje zdjęcia rentgenowskie jako metodę badań nieinwazyjnych. Nowe możliwości stwarza zastosowanie tomografii komputerowej (Computed Tomography - CT), pozwalającej na uzyskanie serii przekrojowych obrazów badanego zabytku, które mogą zostać połączone w obraz trójwymiarowy. Alternatywą dla tej metody może być obrazowanie neutronowe (Neutron Imaging - NI), w którym badany przedmiot penetrowany jest przez neutrony. Uzyskany obraz jest wypadkową właściwości osłabiających materiałów. W odróżnieniu od promieniowania rentgenowskiego, właściwości te nie zależą od gęstości danego materiału. Co za tym idzie, wiele szczegółów niewidocznych na rentgenogramach czy tomogramach może zostać zaobserwowanych na obrazach NI. W artykule omawia się przykłady zastosowań tych metod do badań nad dawnym uzbrojeniem.

Znaczny postęp dokonał się także w dziedzinie datowania radiowęglowego. Z punktu widzenia badań bronioznawczych szczególne znaczenie ma fakt, iż obecnie w przypadku badań metali żelaznych wystarczające są próbki o masie zaledwie kilku gramów. Nowe metody badań radiowęglowych mogą zostać wykorzystane do określenia chronologii zabytków pozbawionych kontekstu archeologicznego lub zachowanych w stanie tak szczątkowym, iż niemożliwym jest zastosowanie innych metod datowania. 
Kolejną dziedziną, w której dokonano w ostatnim okresie wielu przełomowych ustaleń, są analizy składu chemicznego żużla wytopowego i wtrąceń żużla w przedmiotach żelaznych. Analizy takie mogą mieć przede wszystkim zastosowanie przy identyfikacji procesów wytopowych (proces dymarski a proces wielkopiecowy) oraz w przypadku badań proweniencyjnych. W badaniach tych wykorzystuje się obecnie zaawansowane metody statystyki wielowymiarowej, biorąc pod uwagę calych szereg zmiennych, takich jak pierwiastki główne, pierwiastki śladowe oraz stosunki izotopowe. W przypadku studiów proweniencyjnych szczególnie obiecującym wskaźnikiem wydają się być izotopy osmu (os). W artykule wskazuje się szereg studiów nad dawnym uzbrojeniem, w których wykorzystano wyniki badań składu chemicznego wtrąceń żużla dla określenia procesu wytopu metalu, a także dla potrzeb określenia pochodzenia zabytków.

Słowa kluczowe: Prof. Andrzej Nadolski, Prof. Marian Głosek, archeologia, archeometria, archeometalurgia żelaza, badania nieinwazyjne, bronioznawstwo

\section{Grzegorz Żabiński}

Jan Długosz University in Częstochowa

e-mail: g.zabinski@gmail.com

๑) by the author, licensee University of Lodz - Lodz University Press, Łódź, Poland. This article is an open access article distributed under the terms and conditions of the Creative Commons Attribution license CC-BY-NC-ND 4.0 (https://creativecommons.org/licenses/by-nc-nd/4.0/) 